Bioeksperimen

\title{
PENGEMBANGAN SENTRA BUDIDAYA MELON DI PANTAI BOCOR KABUPATEN KEBUMEN MELALUI IMPLEMENTASI EDUCATION FOR SUSTAINABLE DEVELOPMENT
}

\author{
Budi Setiadi Daryono ${ }^{1}$, Purnomo ${ }^{2}$, Yasir Sidiq ${ }^{3}$, Sigit Dwi Maryanto ${ }^{1}$ \\ ${ }^{1}$ Laboratorium Genetika, Fakultas Biologi Universitas Gadjah Mada \\ ${ }^{2}$ Laboratorium Sistematika Tumbuhan, Fakultas Biologi Universitas Gadjah Mada \\ ${ }^{3}$ Program Studi Pendidikan Biologi FKIP Universitas Muhammadiyah Surakarta \\ E-mail: bs_daryono@yahoo.com
}

\begin{abstract}
Bocor Beach, which located in the southern of Kebumen Central Java, has potential for agricultural land. There were sand dunes along the Bocor Beach that serves barrier from wind and waves. Melon is the major commodity in the area. Sand dunes existence must be preserved. It was necessary to develop of melon eco-friendly cultivation. The purpose of program was to develop melon cultivation at Setrojenar village, Kebumen community based on Education for Sustainable Development (ESD). Program activities were included dissemination of sand dunes preservation, introduction of tuber crops as food alternative, planting of Casuarina equisetifolia Linn. for coastal barrier, and mentoring melon cultivation using local materials. The results of activities increased of public participation to sand dunes preservation. Moreover, sand dunes are not damaged and plant coastal barrier well growth, and farmers could harvest melon with good quality. The program has expected to become a role model of developed melon cultivation and preserve the sand dunes for other society.
\end{abstract}

Keywords: education for sustainable development, melon cultivation, sand dunes

\begin{abstract}
Abstrak - Pesisir Pantai Bocor yang terletak di selatan Kabupaten Kebumen, merupakan salah satu lokasi yang berpotensi sebagai lahan pertanian. Sepanjang Pantai Bocor terbentang gumuk pasir yang berfungsi sebagai penghalang angin dan gelombang. Wilayah tersebut dimanfaatkan sebagai lokasi menanam melon yang menjadi komoditas unggulan daerah. Oleh sebab itu dikembangkan melon ramah lingkungan untuk menjaga kelestarian gumuk pasir. Upaya pengembangan melon ramah lingkungan termasuk dalam Education for Sustainable Development (ESD). yang didanai UGM. Pogram ini bertujuan untuk pengembangan masyarakat Desa Setrojenar, Kabupaten Kebumen berbasis ESD. Kegiatan program ini antara lain sosialisasi tentang pelestarian gumuk pasir, pengenalan alternatif tanaman pangan yaitu umbi-umbian, penanaman tanaman Casuarina equisetifolia Linn. sebagai barier, dan pendampingan budidaya melon menggunakan potensi lokal oleh petani. Hasil kegiatan antara lain partisipasi masyarakat tinggi, gumuk pasir tidak rusak, tanaman barier dapat tumbuh baik dan petani dapat panen melon dengan kualitas baik. Kegiatan ini diharapkan dapat menjadi role model bagi masyarakat untuk terus mengembangkan budidaya melon dan tetap menjaga kelestarian gumuk pasir.
\end{abstract}

Kata kunci: budidaya melon, ESD, gumuk pasir 
Bioeksperimen

Volume 2 No. 1, (Maret 2016)

ISSN 2460-1365

\section{PENDAHULUAN}

Education for Sustainable Development (ESD) merupakan upaya mendidik manusia untuk memanfaatkan alam tetapi tetap menjaga kelestariannya. ESD dirancang untuk mendorong kesadaran masyarakat secara keseluruhan, untuk membangun karakter cinta lingkungan dan menerapkan hidup sehari-hari yang ramah lingkungan. Melalui ESD diharapkan dapat mengubah paradigma dan perilaku seluruh komponen masyarakat untuk berpartisipasi dalam implementasi empat pilar pembangunan berkelanjutan, antara lain aspek pembangunan ekonomi yang adil dan berkelanjutan, pelestarian lingkungan hidup, mengembangkan ketahanan sosial, serta mempertahankan keanekaragaman budaya (Prihantoro, 2013).

Sustainable development juga diperlukan sebagai upaya untuk memenuhi kebutuhan saat ini tanpa mengabaikan kebutuhan generasi yang akan datang. Perkembangan ilmu pengetahuan dan teknologi telah mengalami kemajuan sangat pesat, termasuk salah satunya dalam bidang pemuliaan tanaman dan teknologi budidaya pertanian. Beberapa penelitian tentang pemuliaan tanaman dan teknologi budidaya tanaman melon yang berkaitan dengan peningkatan kualitashasil panen dan produksi tanaman melon telah dilakukan. Produk hasil pemuliaan tanaman dan teknologi budidaya tanaman melon yang telah teruji keberhasilannya berdasarkan riset ini perlu diimplementasikan kepada masyarakat melalui konsep ESD sehingga pembangunan berkelanjutan dapat tercapai.

Kabupaten Kebumen merupakan salah satu wilayah yang memiliki kawasan pertanian pesisir yang cukup luas. Salah satu Kecamatan di Kebumen yang memiliki areal pertanian yang luas adalah Kecamatan Buluspesantren yang memiliki luas areal
48.770 km2 dengan 21 Desa, 13.101 rumah tangga, dan populasinya sebesar 53.087 jiwa. Persebaran penduduknya juga cukup tinggi yaitu sebesar $4,44 \%$. Salah satu potensi areal pertanian di Kecamatan Buluspesantren khususnya Desa Setrojenar adalah areal pesisir sekitar gumuk pasir (Bappeda, 2010).

Gumuk pasir dimanfaatkan mayarakat sebagai media bercocok tanam, salah satunya adalah melon. Melon (Cucumis melo L.) merupakan komoditas unggulan di pesisir Pantai Bocor Kebumen (Daryono dkk, 2014). Melon merupakan salah satu tanaman buah dari famili Cucurbitaceae. Tanaman melon termasuk dalam divisio Spermatophyta karena termasuk dalam tumbuhan berbiji (Weihong, 1996). Buah melon merupakan komoditas holtikultura yang telah banyak dikembangkan di Indonesia, baik dalam skala kecil maupun agribisnis (Anindita, 2009). Buah melon memiliki nilai ekonomi yang cukup tinggi dan masih memerlukan pengembangan terutama pada peningkatan hasil dan kualitas buahnya (Daryono dkk, 2011).

Sejak tahun 1997-sekarang, Laboratorium Genetika Fakultas Biologi UGM telah melakukan riset mengenai perakitan kultivar melon unggul antara lain telah dihasilkan kultivar Melodi Gama 1, Melodi Gama 2, Melodi Gama 3, Gama Melon Basket, Tacapa, Hikadi, Hikapel dan Gama Melon Parfum. Berbagai kultivar yang telah dihasilkan tersebut memiliki berbagai keunggulan antara lain memiliki sifat ketahanan terhadap penyakit terutama yang disebabkan oleh virus dan jamur (Daryono dan Genesiska, 2010). Keunggulan lainnya yaitu kultivar Tacapa dan Melodi Gama 3 yang tahan terhadap kondisi lahan kritis (Daryono dkk., 2012).

Dengan potensi keberadaan lahan pesisir pantai selatan Kebumen yang cukup luas maka perlu adanya upaya pemanfaatan 
area pesisir sebagai kawasan pertanian. Langkah awal untuk mewujudkan hal tersebut yaitu dengan terlebih dahulu melakukan penyuluhan, pembinaan, serta pendampingan terhadap petani di kawasan tersebut Pada tahun 2013, telah dilakukan upaya pembinaan awal mengenai pemanfaatan lahan area sekitar gumuk pasir sebagai lahan pertanian yang berwawasan lingkungan, implementasi kultivar-kultivar unggulan hasil rakitan Laboratorium Genetika Fakultas Biologi UGM, dan inovasi teknik budidaya yaitu dengan cara seleksi 2 buah tanaman sekaligus yang dipelihara pada satu ndividu tanaman (Daryono dkk, 2015). Teknik seleksi buah melon tersebut diistilahkan dengan teknik seleksi buah cabang horizontal dan teknik seleksi buah cabang vertikal (Daryono dkk, 2012). Pada tahun 2014, telah dilakukan pengenalan ke kelompok tani tentang perlunya "Integrated Farming" melalui "Role Model" budidaya melon pada demplot milik masyarakat setempat (Daryono dan Maryanto, 2015). Dalam program ini, terjadi proses pembelajaran oleh petani melalui perguruan tinggi sebagai agen of change. Program lain yang telah dilakukan yaitu penyuluhan dan pembelajaran mengenai pentingnya menjaga vegetasi pantai seperti dengan menanam cemara udang dan tanaman Pandanus sebagai barrier pantai agar areal pertanian di kawasan pesisir terlindungi dari bahaya abrasi dan hembusan angin laut. Selain itu, telah dilakukan sosialisasi dan praktek mengenai konservasi gumuk pasir di kawasan pertanian Desa Setrojenar, Kebumen, Jawa Tengah pada generasi muda di Desa Setrojenar. Melalui program ini diharapkan terjadi percepatan pembangunan pada sektor pertanian di kawasan Desa Setrojenar, Kecamatan Buluspesantren, Kabupaten Kebumen, Jawa Tengah dengan tetap terjaga kelestarian lingkungan setempat sesuai dengan tujuan dari konsep ESD.

Program ini bertujuan untuk pengembangan masyarakat Desa Setrojenar, Kabupaten Kebumen berbasis Education for Sustainable Development (ESD).

\section{METODE PELAKSANAAN}

\section{Sosialisasi dan Penyuluhan}

Penyuluhan tentang budidaya melon ramah lingkungan dan konservasi gumuk pasir dilakukan dengan ceramah dan diskusi dengan kelompok tani Desa Setrojenar. Dalam penyuluhan ini dilakukan sosialisasi mengenai konsep Education for Sustainable Development. Pada sosialisasi juga dijelaskan mengenai pentingnya Integrated Farming dan konservasi gumuk pasir bagi kelangsungan pertanian masyarakat setempat. Selain itu, diperkenalkan hasil-hasil penelitian yang telah dicapai Laboratorium Genetika Fakultas Biologi UGM mengenai budidaya tanaman melon. Penyuluhan dan sosialisasi juga dilakukan dengan metode pendekatan secara informal melalui diskusi dengan masyarakat setempat di lapangan.

\section{Pelatihan Mengenai Integrated Farming dan Praktek Implementasi Program}

Pelatihan dan praktek mengenai "Integrated Farming" meliputi konsep sistem pertanian terpadu dengan pemanfaatan material lokal (pupuk kandang, bambu/pelepah kelapa, dsb) sebagai bahan baku pendukung proses budidaya serta perlunya menjaga kelestarian lingkungan dengan melakukan konservasi gumuk pasir dan penanaman tanaman barrier berupa cemara udang dan/atau Pandanus. Pelatihan dan praktek juga meliputi teknologi budidaya melon 
ramah lingkungan yang dilakukan secara bertahap sesuai dengan tahapan budidaya melon. Petani telah dilatih mengenai tahap-tahap budidaya melon, aplikasi mulsa, dan teknis seleksi buah. Pelatihan diberikan dengan simulasi budidaya melon ramah lingkungan melalui tahapan seleksi benih, teknik mulsa, pemeliharaan melon, dan teknik seleksi buah selama 60 hari masa tanam melon oleh pelaksana yaitu Bapak Samidah, beliau merupakan petani melon yang menjadi mitra riset fakultas Biologi. Setelah itu dilanjutkan dengan praktek oleh petani dibawah pengawasan pelaksana kegiatan. Dengan teknologi sederhana tersebut diharapkan petani memiliki kemandirian dalam merekayasa lingkungan lahan pantai.

\section{Pendampingan Berkala}

Selama pelaksanaan kegiatan telah dilakukan juga pembekalan, monitoring, dan pendampingan selama 60 hari kepada perwakilan kelompok tani. Hal ini dimaksudkan agar terjadi transfer ilmu antar petani dan tujuan konsep ESD tercapai.

\section{HASIL KEGIATAN DAN PEMBAHASAN}

\section{Sosialisasi dan Koordinasi}

Tahapan awal kegiatan program implementasi ESD yaitu penentuan lokasi sasaran program (Gambar 1). Selanjutnya dilakukan proses sosialisasi program kepada kelompok tani Desa Setrojenar Kabupaten Kebumen, Jawa Tengah. Sosialisasi dilakukan secara formal maupun non formal. Pada tahap awal sosialisasi dilakukan secara non formal dengan menjelaskan tujuan progam kepada kelompok sasaran (Gambar 1A dan 1B).
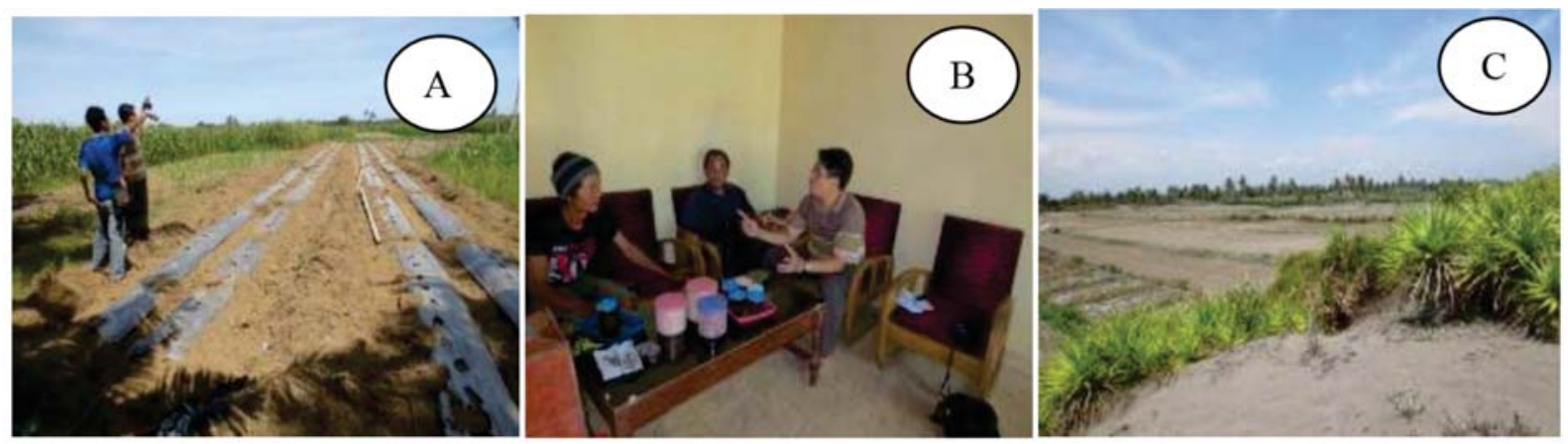

Gambar 1. Lokasi Pesisir Pantai Bocor Desa Setrojenar (A); Sosialisasi program kepada kelompok tani (B), Persiapan lahan melon ramah lingkungan (C)

\section{Implementasi Program}

Tahapan selanjutnya yaitu implementasi program budidaya melon ramah lingkungan di Pantai Bocor, Kabupaten Kebumen, Jawa Tengah. Kegiatan diawali dengan persiapan lahan untuk budidaya. Lahan yang sudah siap kemudian dilakukan pengolahan dengan dibajak, dibuat bedengan, dan pemasangan mulsa. Pada tahapan ini juga dilakukan penyemaian benih melon. Benih melon yang sudah berumur 1 minggu di polybag kemudian ditanam di lahan (Gambar 1C). 
3. Penyuluhan Budidaya Melon Ramah Lingkungan di Area Sekitar Gumuk Pasir

Kabupaten Kebumen merupakan salah satu wilayah yang memiliki kawasan pertanian pesisir yang cukup luas. Salah satu Kecamatan di Kebumen yang memiliki areal pertanian yang luas adalah Kecamatan Buluspesantren yang memiliki luas areal $48.770 \mathrm{~km}^{2}$ dengan 21 Desa, 13.101 rumah tangga, dan populasinya sebesar 53.087 jiwa. Persebaran penduduknya juga cukup tinggi yaitu sebesar 4,44\%. Salah satu potensi areal pertanian di Kecamatan Buluspesantren khususnya Desa Setrojenar adalah areal pesisir sekitar gumuk pasir (Bappeda, 2010). Namun, sistem pertanian yang dilakukan masyarakat setempat masih sangat tradisional dan tidak ramah lingkungan sehingga dapat mengancam keberadaan gumuk pasir serta vegetasi alami pelindung pantai (Daryono dkk., 2015). Untuk itu perlu dilakukan penyuluhan kepada masyarakat petani setempat sehingga kelestarian lingkungan dapat terjaga (Gambar 2).
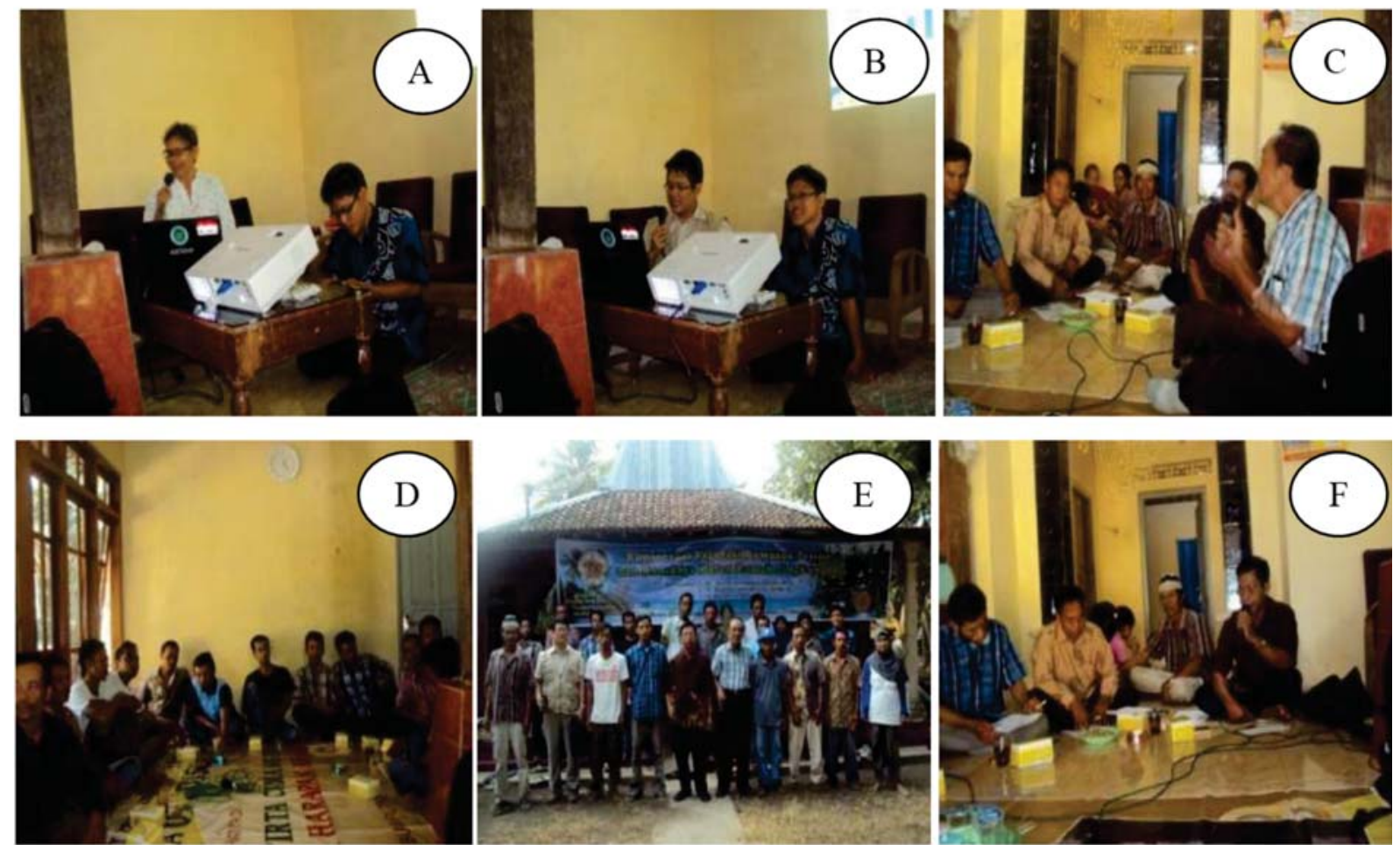

Gambar 2. Penyuluhan kepada kelompok tani di Pesisir Pantai Bocor (A) Dr. Tjut Sugandawaty Djohan, M.Sc. mengenai konservasi area gumuk pasir, (B) Dr. Budi Setiadi Daryono, M.Agr.Sc. mengenai teknologi budidaya melon, (C) Dr. Purnomo, M.S. mengenai pengenalan jenis tanaman umbi-umbian, (D) Suasana penyuluhan, (D) Foto bersama kelompok tani dengan tim pelaksana,

(E) Sambutan Kepala Dusun di Desa Setrojenar, Kabupaten Kebumen, Jawa Tengah. 
Bioeksperimen

Volume 2 No. 1, (Maret 2016)

ISSN 2460-1365

\section{Program Konservasi Area Gumuk Pasir}

Konservasi lingkungan merupakan suatu upaya untuk menjaga kondisi lingkungan tidak rusak atau memperbaiki keadaan lingkungan yang telah rusak sehingga kualitas lingkungan tersebut menjadi lebih baik dari kondisi sebelumnya (Nurjani dkk., 2014). Kegiatan konservasi yang dilakukan pada daerah sasaran berupa upaya menjaga kondisi lingkungan gumuk pasir dari kerusakan akibat kegiatan pertanian yang dilakukan masyarakat setempat. Upaya yang dilakukan salah satunya menanam kembali tanaman vegetasi pantai yang sudah rusak sebagai upaya melindung gumuk pasir dari abrasi air laut. Kegiatan penanaman vegetasi gumuk pasir juga bermanfaat untuk melindungi area pertanian dari terjangan angin laut yang sangat kencang (Daryono dkk., 2014). Kegiatan yang dilakukan pada program ini yaitu penanaman cemara udang pada berbagai lokasi (Gambar 3).
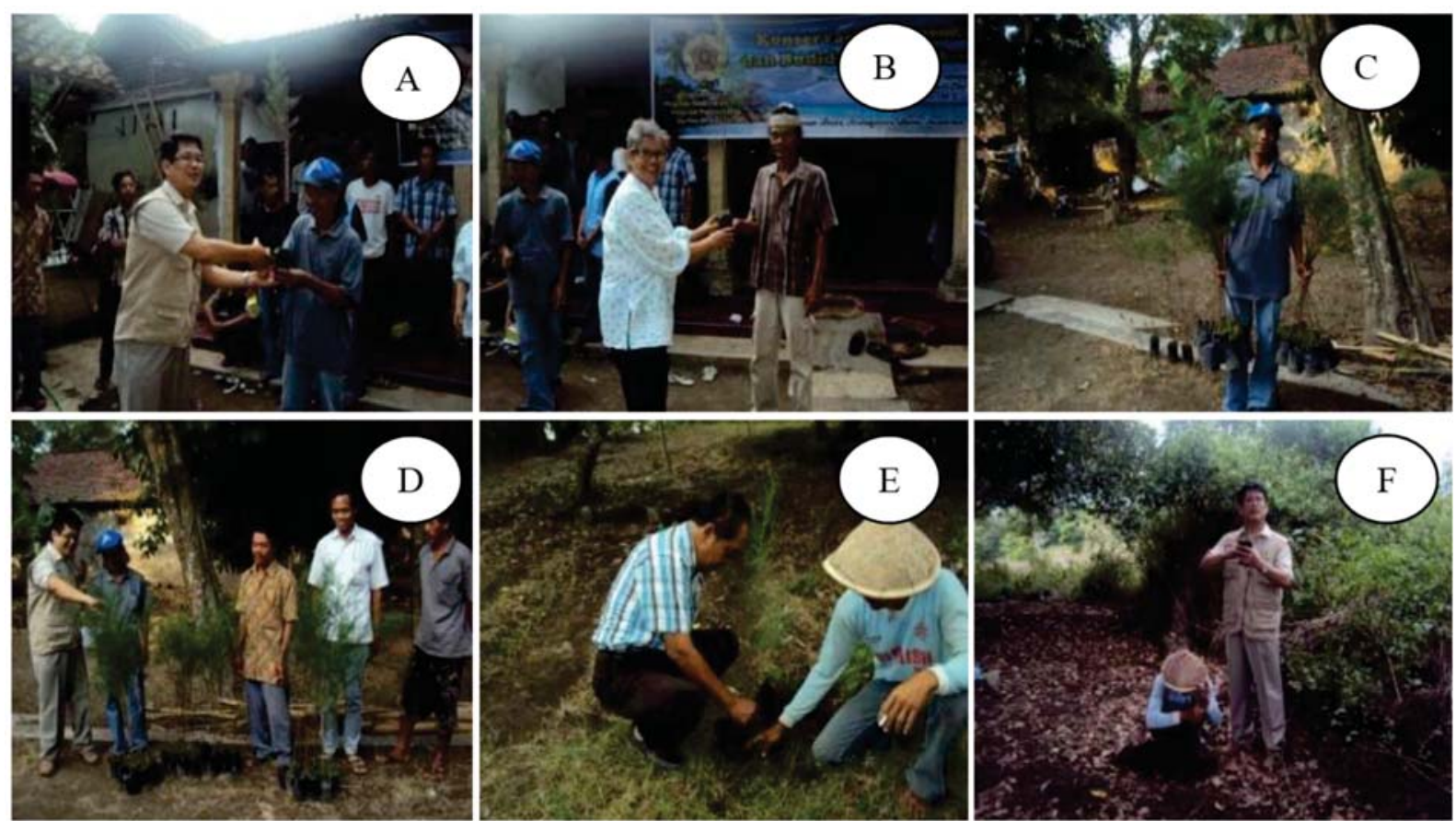

Gambar 3. Penanaman cemara udang di sekitar gumuk pasir, $(A, B)$ Penyerahan bibit cemara udang secara simbolis kepada masyarakat, (C,D) Bibit cemara udang yang diserahkan ke masyarakat Desa Setrojenar, Kabupaten Kebumen, Jawa Tengah, (E, F) Penanaman bibit cemara udang secara simbolis

\section{Budidaya Melon Ramah Lingkungan}

Budidaya melon di kawasan pesisir perlu pembinaan dan peran serta dari perguruan tinggi agar kelestarian lingkungan tetap terjaga. Selain itu, pendampingan kepada petani perlu untuk meningkatkan nilai ekonomi dari produk melon yang dihasilkan (Daryono dkk., 2015). Pendampingan budidaya melon dilakukan mulai dari 
tahap penyiapan lahan, penanaman, perawatan dan pemeliharaan, dan pemanenan (Gambar 4).

Perawatan dan pemeliharaan tanaman melon telah dilakukan hingga masa panen. Perawatan dilakukan kurang lebih 55 hari. Perawatan yang baik perlu dilakukan secara optimum agar didapatkan hasil yang maksimal
(Daryono dkk., 2012). Hasil panen yang baik menjadi percontohan bagi petani lain (role model) sehingga petani di sekitar demplottertarikuntukmembudidayakan melon ramah lingkungan. Salah satu bentuk budidaya ramah lingkungan yaitu menggunakan material lokal yang tersedia di alam (Gambar 5).
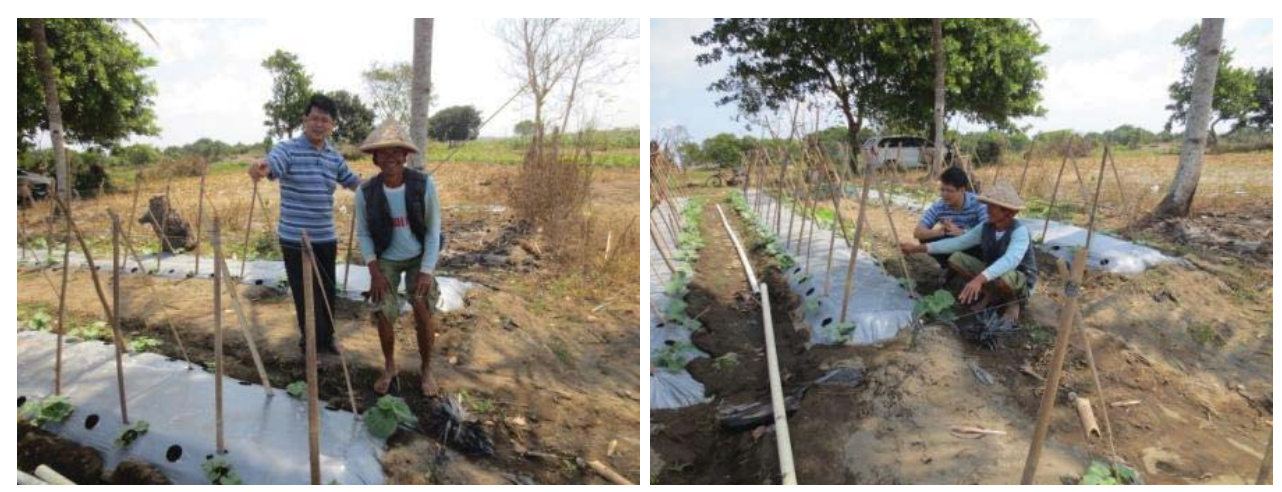

Gambar 4. Pendampingan budidaya melon ramah lingkungan
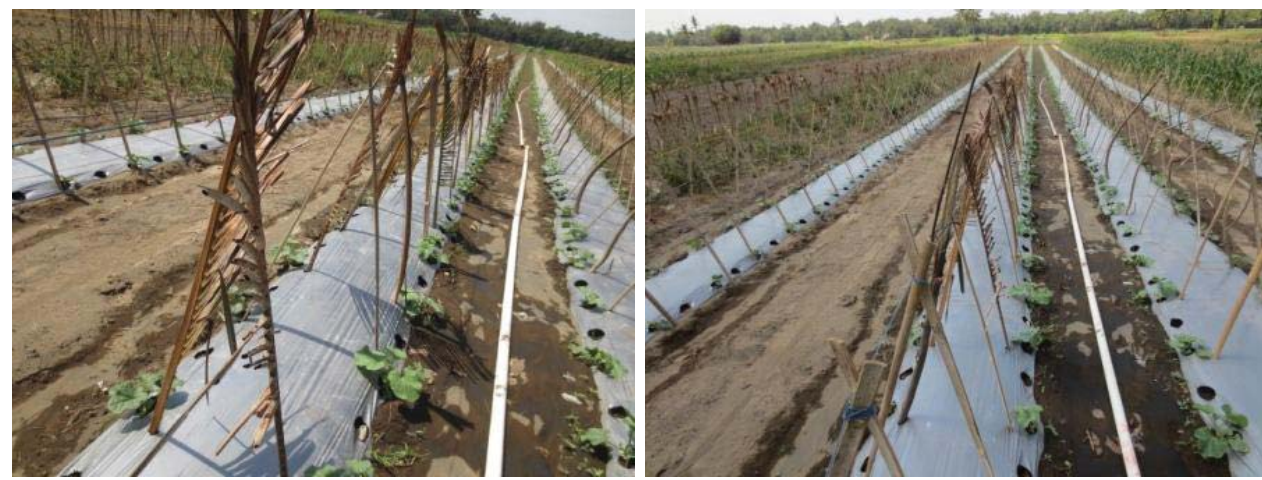

Gambar 5. Budidaya melon ramah lingkungan menggunakan material lokal

Petani menerapkan metode budidaya melon ramah lingkungan. Metode ini memanfaatkan bahan-bahan di lingkungan sekitar demplot seperti pelepah kelapa dan ranting-ranting pohon untuk dijadikan lanjaran dan plantangan. Hal tersebut dilakukan sebagai usaha penerapan kearifan lokal pada budidaya melon ramah lingkungan (Daryono dkk., 2015).
Gambar 6 menunjukkan kearifan lokal yang diterapkan dalam budidaya melon ramah lingkungan di Pantai Bocor, Kebumen.

Perawatan dan pemeliharaan yang optimal akan menghasilkan hasil panen yang baik. Pemeliharaan meliputi pemupukan, penyiraman, seleksi buah, dan pemberian obat-obatan ramah lingkungan (Daryono dkk., 2012). 
Tanaman yang dirawat dengan baik akan menghasilkan tanaman yang baik (Gambar 6).

Penerapan metode budidaya melon ramah lingkungan di Pantai Bocor Kebumen cukup berhasil. Walaupun pada saat perawatan terdapat beberapa kendala terutama infeksi virus dan tingginya intensitas angin laut, tetapi tanaman melon yang ditanam dapat dipanen buahnya. Pada tanggal 24 Oktober dilakukan panen melon di Pantai Bocor, Kebumen, Jawa Tengah.
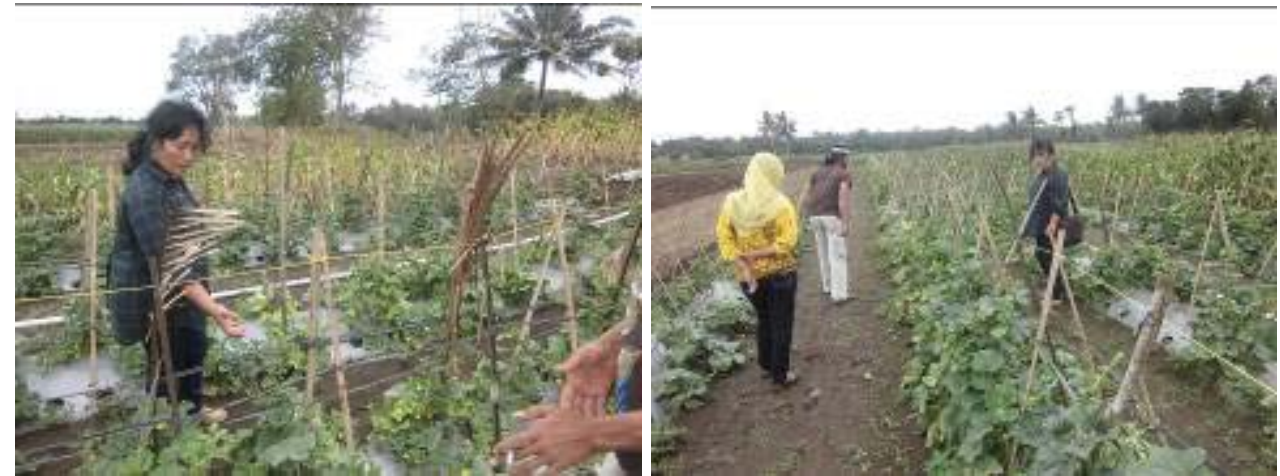

Gambar 6. Kearifan lokal dalam budidaya melon ramah lingkungan. Ranting pohon dan pelepah kelapa yang digunakan oleh petani (tanda panah).

\section{SIMPULAN DAN SARAN}

\section{Simpulan}

Simpulan dari pelaksanaan program ini antara lain:

a. Desa Setrojenar, Kabupaten Kebumen, Jawa Tengah memiliki potensi area lahan pertanian pesisir pantai yang sangat luas namun pemanfaatannya cenderung merusak lingkungan sehingga melalui program Education for Sustainable Development (ESD) ini masyarakat menjadi sadar dalam menjaga lingkungan kawasan pesisir selatan.

b. Komoditas melon menjadi komoditas unggulan masyarakat setempat namun teknik budidaya yang masih konvensional menyebabkan nilai ekonominya masih rendah sehingga dengan adanya program Education for Sustainable Development (ESD) dapat membantu peningkatan ekonomi masyarakat setempat melalui pertanian.

c. Program Education for Sustainable Development (ESD) dapat diterima dan didukung oleh masyarakat Desa Setrojenar, Kabupaten Kebumen, Jawa Tengah sehingga rangkaian program dapat terlaksana dengan baik dan lancar.

d. Program Education for Sustainable Development (ESD) dapat mengimplementasikan empat pilar pembangunan berkelanjutan, meliputi aspek pembangunan ekonomi yang adil dan berkelanjutan, pelestarian lingkungan hidup, mengembangkan ketahanan sosial, serta mempertahankan keanekaragaman budaya.

e. Penerapan kearifan lokal dalam program ESD khususnya untuk budidaya melon ramah lingkungan 
dapat menjadi role model bagi masyarakat di pesisir Pantai Bocor, Kabupaten Kebumen.

f. Budidaya melon berbasis kearifan lokal sangat penting diterapkan oleh masyarakat pesisir Pantai Bocor, Kebumen, sebagai usaha membentuk pola budidaya melon yang berkelanjutan.

\section{Saran}

Program pengabdian dan pemberdayaan masyarakat memerlukan dukungan dana yang sangat besar sehingga perlu peningkatan besaran dana pada kegiatan pengabdian dari perguruan tinggi. Selain itu, perguruan tinggi juga perlu mendapat dukungan dana dari pemerintah, lembaga donor, dan perusahaan-perusahaan skala multinasional sehingga terjadi percepatan pembangunan ekonomi secara luas pada masyarakat sasaran.

\section{UCAPAN TERIMAKASIH}

Tim Pelaksana Kegiatan mengucapkan terima kasih kepada Lembaga Penelitian dan Pengabdian kepada Masyarakat (LPPM) Universitas Gadjah Mada dan kepada Bapak Samidah, Kelompok Tani Desa Setrojenar, Kec. Buluspesantren, Kab. Kebumen Jawa Tengah atas bantuan dan kerjasama dalam budidaya melon. Kegiatan ini didanai oleh Hibah Pengabdian ESD LPPM UGM Tahun 2014 No. LPPM-UGM/712/PM/2014.

\section{DAFTAR PUSTAKA}

Anindita K. A. 2009. Variasi Fenotip dan Pembentukan Warna buah Melon (Cucumis melo L.) kultivar Melodi Gama 1. Seminar. Fakultas Biologi Universitas Gajah Mada.

Bappeda. 2010. Rencana Pembangunan Jangka Panjang Daerah
Kabupaten Kebumen Tahun 20052025. Sumber:http://bappeda. kebumenkab.go.id/RPJP.pdf

Daryono dan Genesiska. 2010. Peningkatan Usaha Agribisnis Benih Holtikultura dengan Penerapan Strategi Pemuliaan Tanaman untuk menghadapi CAFTA. Dalam Buku Pertanian Terpadu untuk Mendukung Kedaulatan Pangan Nasional. BPFEYogyakarta. Hal. 217-237.

Daryono, B.S., S.D. Maryanto, I.N. Huda. 2011. Kebangkitan Pertanian Indonesia. Kebun Pendidikan Penelitian Pengembangan Pertanian (KP4) UGM.

Daryono, B.S., Hayuningtias, S.D., Maryanto, S.D. 2012. Perakitan Melon (Cucumis melo L.) Kultivar Melodi Gama 3 Dalam Rangka Penguatan Industri Pertanian Nasional. Prosiding Seminar Nasional Dan Call For Paper EP UNNES.

Daryono, B.S., Sidiq, Y., dan Maryanto, S.D. 2014. Budidaya Tanaman Melon Ramah Lingkungan Sekitar Gumuk Pasir Pantai Kebumen dalam Perubahan Iklim dan Pemanfaatan SIG di Kawasan Pesisir. Gadjah Mada University Press. Hal 227257

Daryono, B.S. dan Maryanto, S.D. 2015. Application of Integrated-Farming Concept: Cultivation of Melon (Cucumis melo L.) in the KarstCoastal Area, Gunungkidul, D.I. Yogyakarta, Indonesia as GreenAgriculuter Model. Health and The Environment Journal, Vol. 6 (1).

Daryono, B.S., Ibrohim, A.R., Maryanto, S.D. 2015. Aplikasi Teknologi Budidaya 
Melon (Cucumis melo L.) Kultivar Gama Melon Basket di Lahan Karst Pantai Porok Kabupaten Gunungkidul D.I. Yogyakarta. Jurnal Biogenesis, Vol 3 (1) hal 39-46.

Davis, P.H., and V.H. Heywood. 1973. Principles of Angiosperm Taxonomy. Robert E. Krieger Publishing Company Huntington, New York. Pp. 116-119

Departemen Pertanian. 2008. Membangun Holtikultura Berdasarkan Enam Pilar Pengembangan. Direktorat Jenderal Hortikultura.

Departemen Pertanian. 2009. Basis Data Statistik Pertanian.Departemen Pertanian Republik Indonesia. http://www.deptan.go.id/

Fukino,N., M. Kunisiha, and S. Matsumoto. 2004. Characterization of Recombinant Inbred Lines Derived from Crosses in Melon (Cucumis melo L.) PMAR No.5 Haruke No 3. Jurnal: Breeding Science (54):141145

Nurjani, E., D.S. Aji dan A. Putranto. 2014. Perubahan Iklim Sebagai
Isu Lingkungan Global dalam Perubahan Iklim dan Pemanfaatan SIG di Kawasan Pesisir. Gadjah Mada University Press. Hal 129162

Paje, M. M dan H. M. Van der Vossen. 1994. Cucumis melo L., Prosea Foundation, Bogor. 8:153-157

Perin, C., C. Dogimon, N. Giovinazzo, D. Besomes, L.Guitton, L. Hagen and M. Pitra. 1999. Genetic Control and Linkages of Some Fruits Characters in Melon. Cucurbit Genetic Cooperative Report 22: 16-18.

Prihantono, F. 2013. Pendidikan untuk Pembangunan Berkelanjutan. Sumber: http://forgreen.blogspot. com

Robinson and Decker-Walker. 1999. Cucurbits. New York, USA : Cab International 198 Madison Avenue, pp. 80-90.

Weihong, G. M. 1996. Comparison of Stacking and Nonstacking on Melon and Musk melon (Cucumis melo L.) Production. ARC Training. 